\title{
PSYCHE
}

VOL. XX.

AUGUST, 1913.

No. 4

\section{ON A COLLECTION OF THYSANOPTERA FROM PANAMA.}

\author{
By J. Douglas Hood, \\ United States Biological Survey.
}

A small collection of Thysanoptera made in the Canal Zone, Panama, by Mr. James Zetek of the Isthmian Canal Commission during the year 1912, furnishes the basis for the present article. There appear to be no published records of any thrips occurring in that region. This fact, together with the finding of two species new to science and the knowledge gained of the distribution of the several other species, has made the collection of more than passing interest. Under each species mentioned is given a summary of its known geographical distribution, together with such additional locality records as are furnished by the specimens in all collections to which I have had access.

Franklinothrips vespiformis Crawford.

Distribution: Managua, Nicaragua (Crawford); Florida (Back); Brownsville, Texas; Miraflores, Canal Zone.

An easily recognized species, very distinct from Eolothrips in which it was originally described. Known previously only from Nicaragua and Florida, but quite common in sweepings from grass and weeds at Brownsville, Texas, and in the Canal Zone.

Frankliniella insularis Franklin.

Distribution: Barbados (Franklin); Guadalajara, Mexico (Crawford); Brownsville, Texas (Russell); Monterey, Mexico; Miraflores, Canal Zone, Panama.

Probably the most abundant thrips in Central America. The specimens from Miraflores were taken in "sweepings along a stream and in small clearings." 
Frankliniella minuta Moulton.

Distribution: California (Moulton, Crawford); Brownsville, Texas; Topo Chico (near Monterey), Mexico; Ancon, Canal Zone, Panama.

A common flower-frequenting species of the southwest, known previously only from California.

Heliothrips hæmorrhoidalis Bouché.

Distribution: Europe; Asia; Australia; North America; Hawaiian Islands; St. Vincent and Barbados Islands (Franklin); Ancon, Canal Zone, Panama.

A cosmopolitan greenhouse pest, indigenous to tropical and subtropical America. One specimen was taken at Ancon, in sweepings.

Liothrips zeteki sp. nov.

(Figs. 1, 2.)

Female: Length about $2.2 \mathrm{~mm}$. Color dark blackish brown or black; thorax, tarsi, and tip of tube slightly paler; third antennal segment abruptly pale yellow.

Head about 1.5 times as long as wide, broadest across or just behind eyes; cheeks nearly straight, subparallel, slightly converging posteriorly, at extreme base with distinct collar-like widening; vertex elevated, produced, anterior ocellus distinctly overhanging; dorsal and lateral surfaces slightly roughened with transverse lines, set with several short spines; postocular bristles truncate, about as long as eyes. Eyes one third as long as head. Posterior ocelli opposite anterior third of eyes. Antennæ 1.6 times as long as head, moderately slender; segments 1 and 2 nearly concolorous with body, 2 slightly paler in apical half; 3 pale yellow; 4-8 nearly black, 4 paler in outer apical half; segments 3-6 clavate, pedicellate; 7 oblong, pedicellate; 8 subconical; sense cones slender, colorless, formula: $3,0-1 ; 4,1-2+1 ; 5,1-1+1 ; 6$, 1-11; 7 with one on dorsum near apex. ${ }^{1}$ Mouth cone subacute, nearly attaining base of prosternum.

Prothorax about .6 as long as head, and (inclusive of coxæ) about 2.4 times as wide as long; all bristles present, long, stout, truncate, nearly black in color, the two pairs near the posterior angles longest; coxal bristle truncate, about equal in length to anterior marginals. Pterothorax wider than prothorax and a little wider than long; sides straight, slightly converging posteriorly. Wings long, closely fringed, not narrowed at middle; fore wings brown in basal fifth, margined with a slight shading of brown, and with a median brown bar extending the entire length of the wing; subapical fringe on posterior margin double for 14-16 hairs; hind wings brown at extreme base and with a submedian brown bar which becomes paler toward apex of wing. Legs moderately stout; fore tarsi unarmed.

\footnotetext{
${ }^{1}$ The explanation of the formula used in the description of the antennal sense cones has been given by the writer in Ann. Ent. Soc. Amer., vol. I, no. 4, p. 285; and in Ent. News, vol. XX, no. I, p. 29 , footnote.
} 
Abdomen large, wider than pterothorax, tapering roundly from segment 6 to base of tube. Tube about .8 as long as head, 1wice as wide at base as at apex, tapering evenly. Abdominal bristles moderately long, black, nearly all blunt; terminal bristles slightly shorter than tube.

Measurements of holotype: Length $2.2 \mathrm{~mm}$; head, length $.336 \mathrm{~mm}$., width .228 mm.; prothorax, length $.185 \mathrm{~mm}$., width (inclusive of coxæ) $451 \mathrm{~mm}$.; pterothorax, width $.504 \mathrm{~mm}$.; abdomen, width $.600 \mathrm{~mm}$.; tube, length $.276 \mathrm{~mm}$., width at base $.114 \mathrm{~mm}$., at apex $.054 \mathrm{~mm}$. Antennal segments: $1,48 \mu ; 2,60 \mu ; 3,99 \mu ; 4,84 \mu$; $5,81 \mu ; 6,72 \mu ; 7,63 \mu ; 8,36 \mu$; tolal length of antenna, .54 mm.; width at segment 4, .046 mm.

Male: Smaller and slenderer than female; otherwise nearly identical.

Measurements of allotype: Length $1.92 \mathrm{~mm}$; head, length .288 mm., width .204 mm.; prothorax, length $.138 \mathrm{~mm}$., width (inclusive of coxæ) $.388 \mathrm{~mm}$.; pterothorax, widih $.408 \mathrm{~mm}$; ; abdomen, width $.408 \mathrm{~mm}$.; tube, length .252mm., width at base $.087 \mathrm{~mm}$., at apex $.045 \mathrm{~mm}$. Antennal segments: $1,45 \mu ; 2,54 \mu ; 3,87 \mu$; $4,78 \mu ; 5,73 \mu ; 6,67 \mu ; 7,58 \mu ; 8,31 \mu$; total length of antenna, $.49 \mathrm{~mm}$.; width at segment $4, .039 \mathrm{~mm}$.

Described from two females and one male taken by Mr. James Zetek in January, 1912, in sweepings, Miraflores, Canal Zone, Panama.

The antennal coloration and general structure allies this species closely to varicornis Hood, described from Mexico. It differs conspicuously, however, in the much longer head, shorter antennæ, and the truncate postocular and prothoracic bristles. I take pleasure in naming it for its collector, an enthusiastic, energetic entomologist and a friend of many years.

Leptothrips aspersus Hinds.

Distribution: United States: Amherst, Mass., (Hinds); Orlando, Fla. (Back); Southern California (Crawford); Highspire, Pa.; Cabin John and Plummer's Island, Md. (near Washington, D. C.); Washington, D. C.; Bloomington, Ind.; Boskydell, (near Carbondale), Carbondale, Cobden, Dubois, Duqoin, Grand Tower, Havan, Hillery (near Danville), Makanda, Metropolis, Muncie, Murphosboro, Odlin, Parker, Pulaski, St. Joseph, Tennessee, Urbana, and White Heath, all in Illinois; Wittenburg, Mo.; Brownsville, Texas. Mexico: Gualalajara (Crawford), Matamoros, Monterey, and Topo Chico (near Monterey). West Indies: Barbados (Franklin). Panama: Miraflores, Canal Zone.

Throughout its range this species varies but little except in size, though the Panama specimens differ almost constantly in 


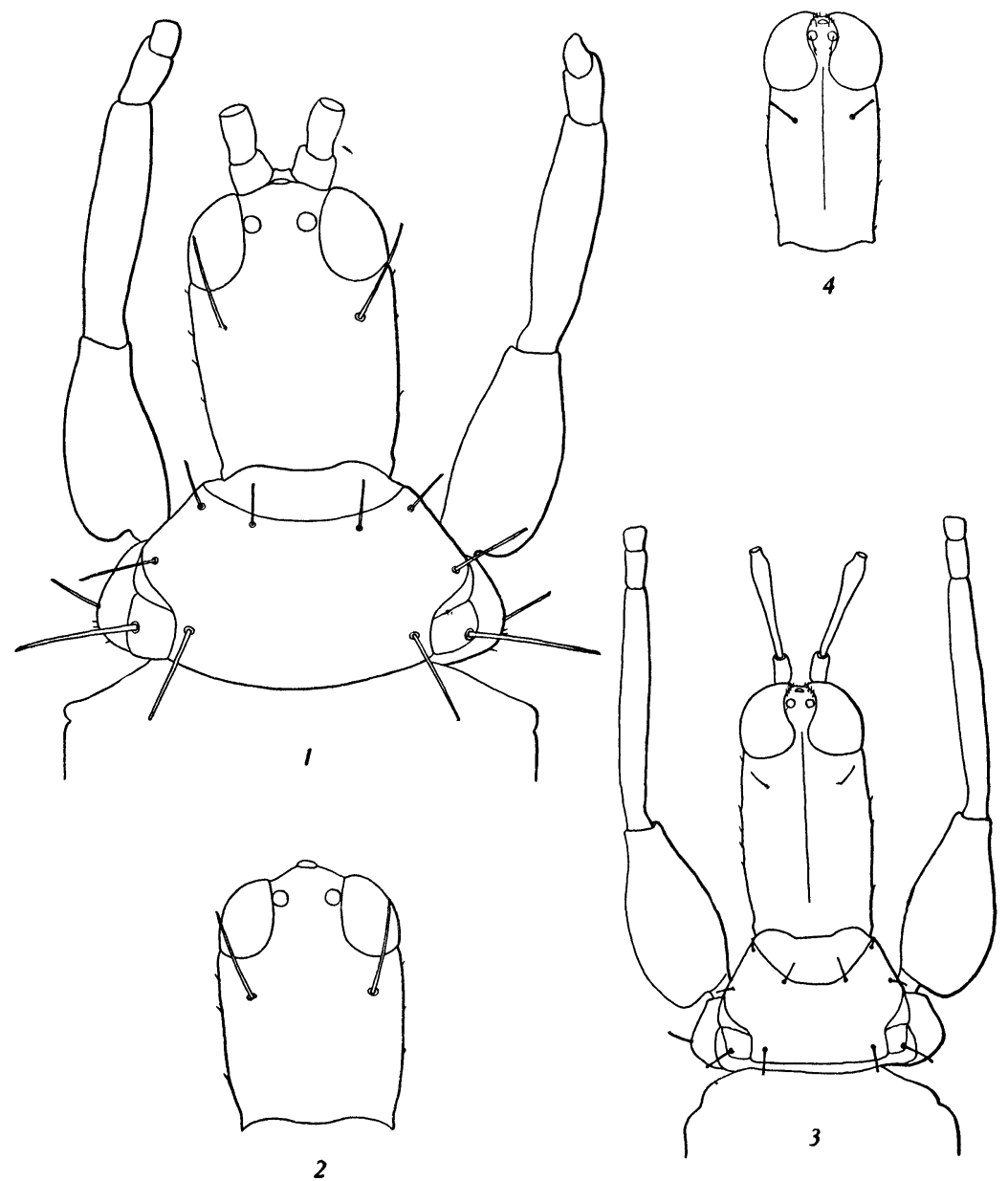

Fig. 1. Liothrips zeteki sp. nov., head and prothorax, female.

Fig. 2. Liothrips zeteki, head of male.

Fig. 3. Polyommatothrips vigilans sp. nov., head and prothorax, female.

Fig. 4. Polyommatothrips vigilans, head of male. 
having a dark median vitta in the basal half of the fore wings, Thirteen specimens were taken at Miraflores in January, in "sweepings along a stream and in small clearings."

\author{
Polyommatothrips vigilans sp. nov.
}

(Figs. 3, 4.)

Female: Length about $3.0 \mathrm{~mm}$. Color blackish brown, with abundant maroon hypodermal pigmentation; abdominal segments 3-8 at base with a pair of small latero-dorsal white blotches (as in Acanthothrips nodicornis Reuter); fore tarsi, ends of fore tibiæ, and apex of fore femora yellow; antennæ largely yellow; tube paler in apical half.

Head twice as long as wide, broadest midway between eyes and base, compressed and subcarinate above; dorsal and lateral surfaces finely subreticulate, sparsely and briefly spinose, without prominent tubercles; cheeks gently arcuate, with short collar-like thickening at base; postocular bristles short, only one third as long as eyes, slightly dilated at tip. Eyes very finely and closely faceted, somewhat protruding, less than one third as long as head, extending inward nearly to the median line and almost completely surrounding the ocelli. Ocelli anterior, equidistant, subapproximate. Antennæ 1.6 times as long as head, very slender; segments 3-6 clavate, abruptly narrowed apically, urn- or vase-shaped (as in Acanthothrips); 7 fusiform-truncate, closely united to 8 , which is conical; segments 1 and 2 pale brownish yellow; 3 yellow, clouded apically, nearly black at apical constriction; 4. yellow, nearly black at extreme base and apex, clouded in apical third;5 and 6 yellow, black at extreme base, washed with blackish brown in apical half and two thirds, respectively; 7 and 8 blackish brown; sense cones long, slender, broad at base, those on segment 3 less than one third the length of segment; formula: 3 , $1-2 ; 4,1-2^{+1} ; 5,1-1 ; 6,1-1 ; 7$ with one on dorsum near apex. Mouth cone and palpi very long, acute, nearly attaining metasternum.

Prothorax deeply emarginate in front, its median dorsal length about two thirds the lateral length, the latter half that of head and half the width across fore coxæ; all usual bristles present, short, slightly dilated at tip. Pterothorax slightly wider than long, broader than prothorax; sides nearly straight, slightly converging posteriorly. Wings long, closely fringed, not narrowed at middle; fore wings about one and one half times as wide at basal fifth as at middle; scale and the region of the three subbasal spines dark brown; a dark bar occupies the anal half of the second fourth of the fore wings, darkest toward the median line, along which it is continued nearly to apex of wing; costal half of second fourth of fore wings darkened with brown; subapical fringe on posterior margin of fore wings double for about 32 hairs; hind wings brown at base and with prominent dark median vitta reaching nearly to apex. Legs long and slender; fore femora swollen; fore tarsi unarmed.

Abdomen slender, seemingly narrower than pterothorax. Tube less than half as long as head and more than half as wide at apex as at base, opaque black in basal half, brown in apical half. Marginal abdominal bristles (excepting those on segment 9, which are pointed and fully twice as long as tube) moderately short, blunt; terminal bristles lacking in the type. 
Measurements of holotype: Length $3.02 \mathrm{~mm}$; head, length $.576 \mathrm{~mm}$., width $.293 \mathrm{~mm}$.; prothorax, length from anterior angle to base $.288 \mathrm{~mm}$., width (inclusive of coxæ) $.564 \mathrm{~mm}$; pterothorax, width $.600 \mathrm{~mm}$; abdomen, width $.576 \mathrm{~mm}$.; tube, length $.252 \mathrm{~mm}$., width at base $.093 \mathrm{~mm}$., at apex $.054 \mathrm{~mm}$. Antennal segments: $1,72 \mu ; 2,84 \mu ; 3,231 \mu ; 4,171 \mu ; 5,159 \mu ; 6,96 \mu ; 7,81 \mu ; 8,42 \mu$; total length of antenna, $.93 \mathrm{~mm}$.; width at segment $3, .048 \mathrm{~mm}$.

Male: Smaller and slenderer than female (length about $2.8 \mathrm{~mm}$.). Eyes larger, very prominent. Antennæ longer and more slender. Terminal abdominal bristles one and one half times as long as tube. Otherwise nearly as in female.

Measurements: Length $2.83 \mathrm{~mm}$.; head, length $.540 \mathrm{~mm}$., width across eyes .270 $\mathrm{mm}$.; prothorax, length from anterior angle to base $.240 \mathrm{~mm}$., width (inclusive of coxæ) $.420 \mathrm{~mm}$.; pterothorax, width $.468 \mathrm{~mm}$.; abdomen, width $.420 \mathrm{~mm}$.; tube, length $.252 \mathrm{~mm}$., width at base $.093 \mathrm{~mm}$., at apex $.054 \mathrm{~mm}$. Antennal segments: $1,72 \mu ; 2,84 \mu ; 3,231 \mu ; 4,174 \mu ; 5,165 \mu ; 6,117 \mu ; 7,87 \mu ; 8,48 \mu$; total length of antenna, $.98 \mathrm{~mm}$; width at segment $3, .045 \mathrm{~mm}$.

Described from one individual of each sex, taken in sweepings near Paraiso, Canal Zone, Panama, by Mr. James Zetek.

This anomalous insect differs from its congener silvestrii, described from Argentina, in several important particulars, the most noticeable being the absence of spiniferous genal tubercles, the deeply emarginate pronotum, the abdominal coloration, and the size. Minor additional differences may also be noticed in the form of the head, the length of the eyes, the comparative lengths of the third, fourth, and fifth antennal segments, and the lengths of the antennal sense cones and the prothoracic bristles. The compressed dorsum of the head is normal and especially interesting, occurring to the best of my knowledge in no other species. Another remarkable point of structure, and which was not mentioned in the original generic description, lies in the mode of insertion of the antennæ, these being attached to the ventral surface of the head and in life apparently directed diagonally downward, nearly at right angles to the top of the head. The emargination of the pronotum allows the head to be tipped back at an angle of about forty-five degrees. 

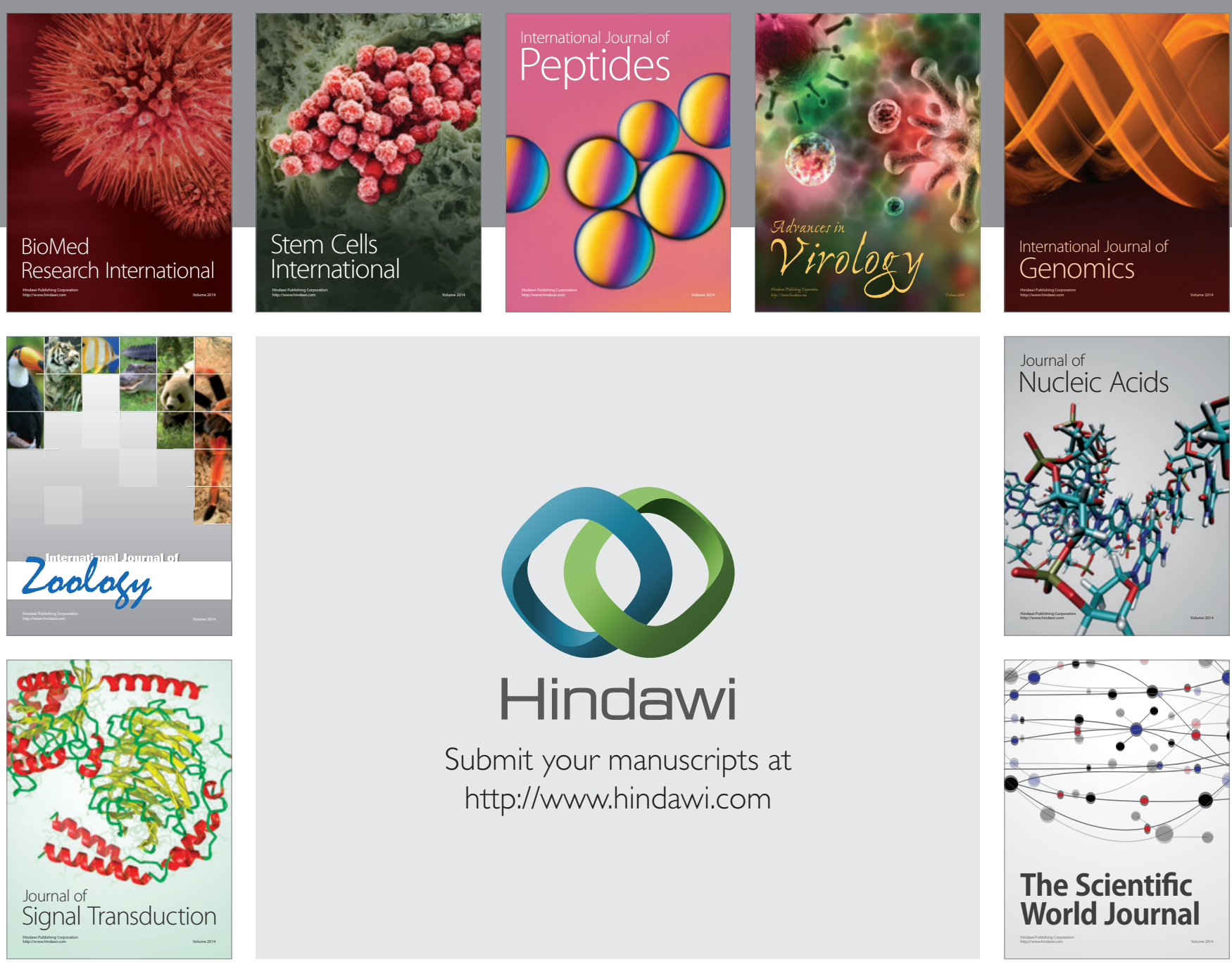

Submit your manuscripts at

http://www.hindawi.com
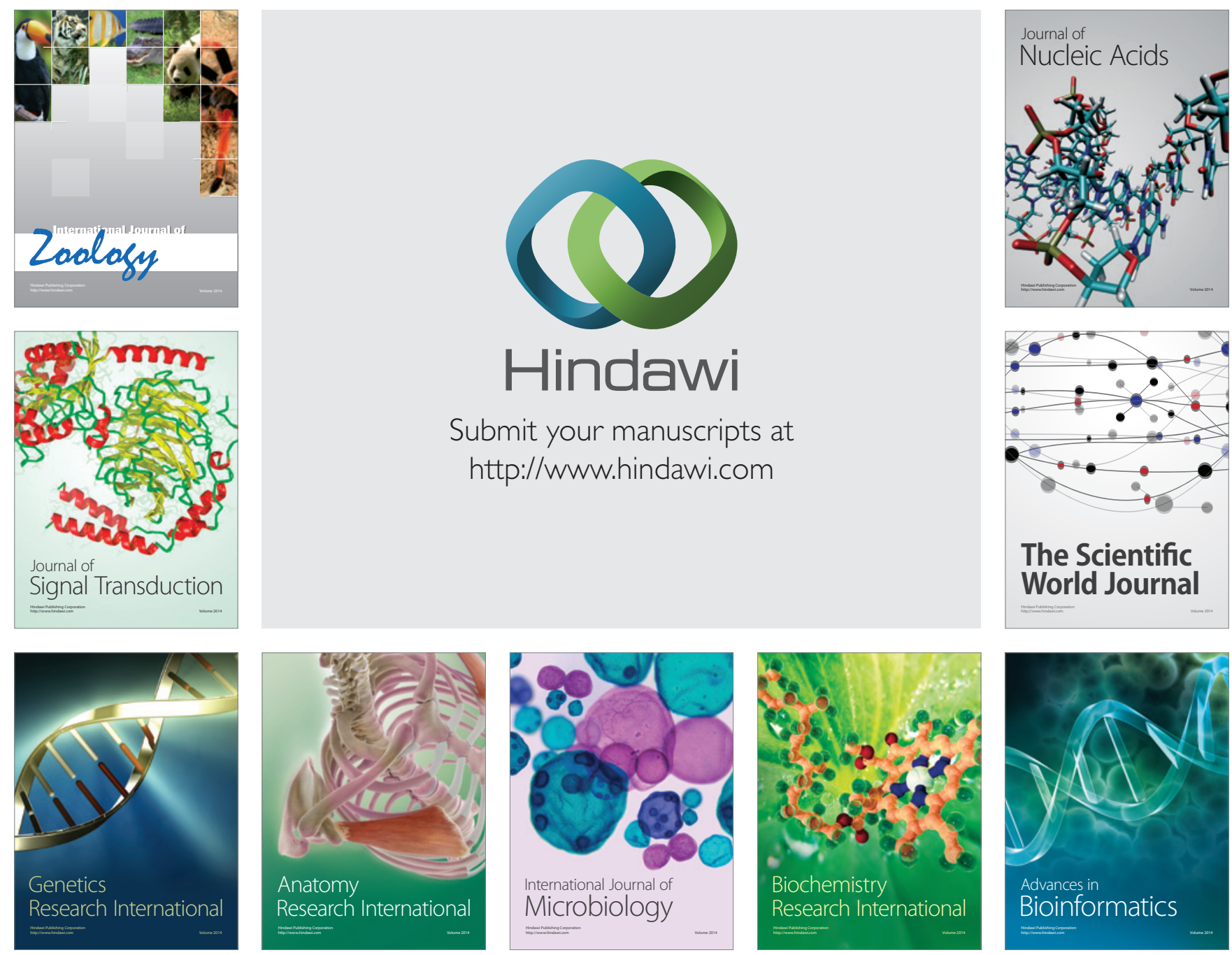

The Scientific World Journal
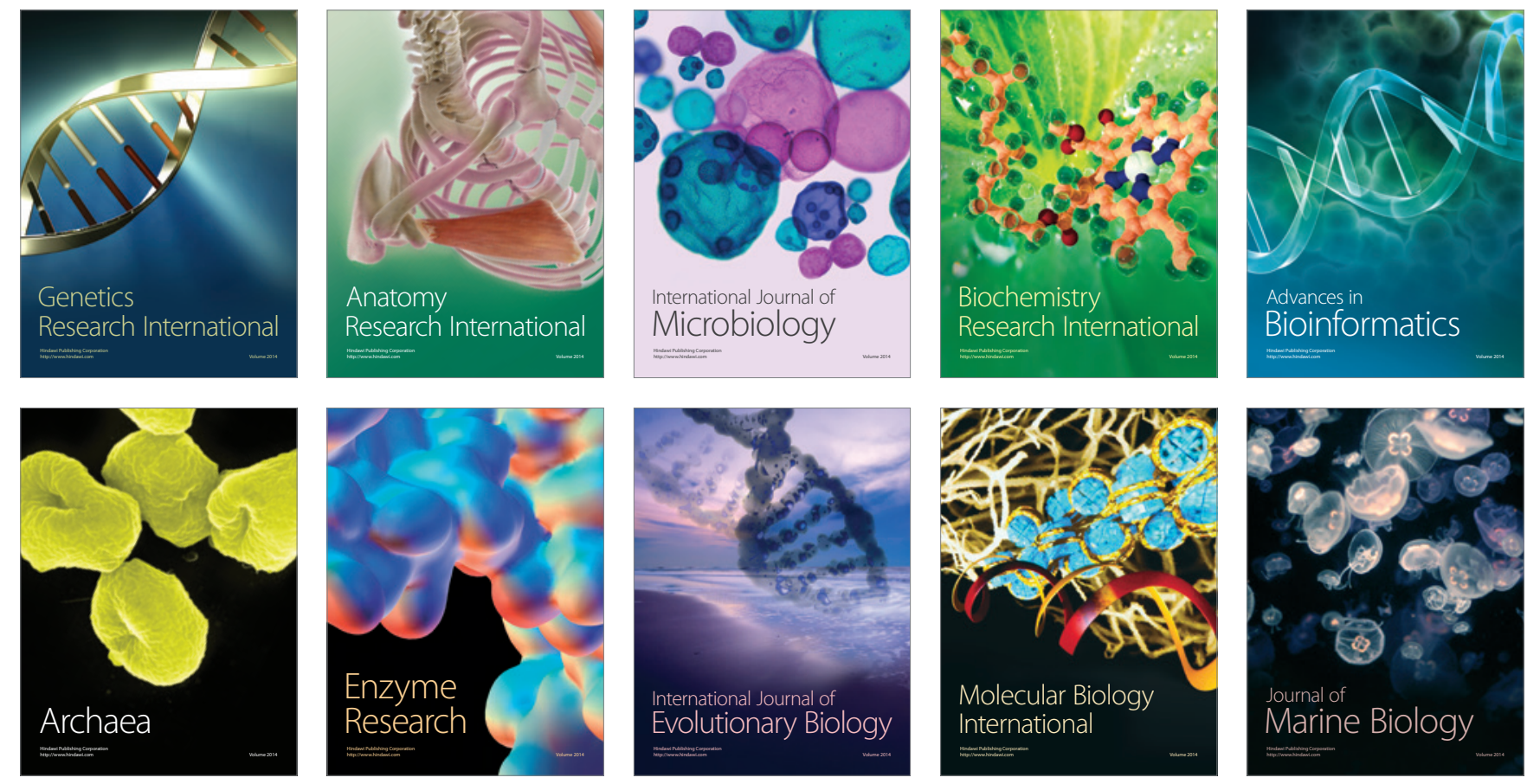